\title{
CHAPTER 4 \\ Does Secularism Face a Serious Threat in Turkey?
}

\author{
Metin Heper
}

\section{Introduction}

In two interviews conducted in May 2007, prominent Turkish social scientist Şerif Mardin suggested that if the conditions one day become conducive for it, the bigots in his country may exert an effective communal pressure on the secularly oriented to adopt certain Islamic life styles and the secularly oriented may find it difficult not to act in conformity with the set of norms imposed on them. ${ }^{1}$

Mardin added that such a development may take place independently of the governing Justice and Development Party (JDP), which, according to some, has always had the hidden agenda of bringing back a state based on Islam and, which, according to others, is not a political party that cherishes political Islam. ${ }^{2}$ According to proponents of the latter view, the JDP is led by people who in their private lives act as devout Muslims but in their public lives pursue secular policies. ${ }^{3}$ Mardin, who is inclined toward the second view, thinks that the JDP would be no match for the bigots if a competition were to take place between the two on reshaping lifestyles in society. ${ }^{4}$

Mardin has not committed himself one way or another on the question of to what extent the emergence of communally based Islamic fundamentalism is likely in Turkey, if at all. He merely pointed out that in the past the phenomenon of Islamic communal pressure on those who seemed not as 
devout as the bigots themselves had been a fact of life and thus implied that it might again be the case. Mardin further pointed out that the conditions conducive for the revival of the communal Islamic pressure in question, as well as the very nature of that pressure, has remained an enigma, and that it was high time that social scientists try to make heads or tails of both phenomena. ${ }^{5}$

The question Mardin raised in May 2007 continues to have significance for Turkish modernization in general, and democracy in that country in particular. Between December 2007 and July 2008, another prominent Turkish scholar, Binnaz Toprak, along with three journalists, carried out in-depth interviews with 401 persons in 13 provinces, including Istanbul. In this nonrepresentative study, Toprak and other researchers explored the manner in which Islamists keep the secularists under pressure. ${ }^{6}$

What Mardin has thought probable and what Toprak and others have given examples of is that the threat the secularists face in Turkey continues to be a very contentious issue. This chapter suggests that the cognitive revolution that the founders of the Turkish Republic tried to make has been quite successful and as a result: (1) the Turkish people, the pious as well as nonreligious, have come to have loyalty to the secular republic; (2) on the whole the pious are secularized and voluntarily separate religion and politics; and, consequently, (3) the loyalties of the pious to the secular state do not contradict their religiosity.

\section{The Cognitive Revolution}

Following the inception of the republic in 1923, the founding fathers led by Mustafa Kemal (Atatürk) attempted at a cognitive revolution. ${ }^{7}$ The new Turk was no longer going turn to the Book, but would use his or her own reasoning faculties to make important decisions. To accomplish this goal, among other things, the caliphate was abolished; the provision that Islam was the religion of the state was removed from the (1924) constitution; religious schools and orders were closed; the Arabic scripture was replaced by the Latin one; Sunday, not Friday, was rendered the day of the rest; the Islamic lunar calendar was replaced by Gregorian calendar; and men were obliged to wear the Western-style hat in place of the fez, which at the time was assumed to be a symbol of Islam. ${ }^{8}$ Most significant, people had to submit to a system of education couched in the scientific terms of the West. ${ }^{9}$ In Atatürk's view, what he and his associates were trying to institutionalize in Turkey was a technique of how to think, not a prescription of what to think. ${ }^{10}$

The founders must have hoped that the cognitive revolution they were trying to bring about would in time lead to a cultural revolution. This was 
particularly the case in respect to women's dress; Atatürk criticized women who sported the Iranian chador like çarşaf but did not force them to dress in a particular style. The founders' conception of modernization was in effect Westernization, an integral dimension of which was democratization. The transition to democracy was also accomplished, though relatively late in the game (1945).

On the whole, the above project of the founding fathers, later referred to as Kemalism, had been a successful project, for several reasons. First, an overwhelming majority of the people in Turkey began to move away from superstitions and a dogmatic way of thinking. In 1964, for villagers, a nearby town or even a city was no longer "a conglomerate of humanity profaned by infidels." 11 In 1996, in the central Anatolian city of Konya, which had been one of the most religiously conservative cities in Turkey, an English-medium school that also offered an intensive religious instruction attracted good students because of its medium of instruction, not because of its emphasis on religious topics. ${ }^{12}$ Second, people began to see themselves as part of a secular nation and not as part of a religious community, as had been the case in the Ottoman times. In the late 1960s workers in a textile factory in the western city of İzmir (Smyrna) were asked to identify themselves, and while 37.5 percent considered themselves as "Muslims," 50.3 percent said they were "Turks," and the rest referred to themselves with other identities. ${ }^{13}$ In a nationwide survey conducted in 1994, when asked how they considered themselves, 69 percent responded that they were "Turks," 21 percent "Muslim Turks," 4 percent "Muslims," another four percent "Kurds," and 2 percent another identity. ${ }^{14}$ A third reason for Kemalism's success is that democracy came to be consolidated in Turkey; no significant section of the populace thinks an authoritarian political regime is better than democracy. It is true that the military in Turkey intervened several times, in 1960, 1971, and 1980, taking power into its hands and in 1997, in concert with some civil societal groups, obliging a coalition government to resign. However, except for a faction among those who intervened in the 1960, officers have never toyed with the idea of staying in power for good, as their counterparts in South America and in the other Middle Eastern countries have often done. Officers have always intervened with the sole purpose of "saving democracy from itself" and returned to the barracks when they thought that that mission was accomplished.

\section{Why Are the Secularists Concerned?}

From the early republican times to the present, certain Islamic developments or discourses rendered the secularists in Turkey very much concerned about 
the possibility of some retrogressive groups succeeding to form a state based on Islam. ${ }^{15}$ To give a few examples, the Progressive Republican Party formed in 1924 was against some of the Kemalist reforms that were in the making. The party was closed by the government the next year. The leaders of the Kurdish rebellions in 1921-1938 tried to mobilize people by arguing that Islam was under threat. The Republican Free Party of 1930 was considered to have opened up a political space for the antirepublican tendencies in the country, and consequently its leader was "persuaded" to close the party. That same year a young officer was beheaded in the western town of Menemen in a mini-rebellion orchestrated by the Nakshibandi religious order. In the 1950s the so-called Ticani religious order smashed statues of Atatürk. From 1969 onward, religiously oriented political parties began to compete in national elections. Although in later decades their discourse became one of "neither the state nor religion should interfere in the affairs of the other," initially these political parties perceived an essential contradiction between Islam and secularism. On July 30, 1980 the leader of the first four of these political parties, Necmettin Erbakan, made the following declaration at a rally of Islamists, where placards proclaimed "Sharia or death" and "One caliphate, one state": "We should take as our guide the industry, determination, and love of jihad [that resulted] in the conquest of Istanbul. May you, the new army of the Sultan Fatih Mehmet, be victorious and your holy struggle be blessed. Be prepared, we shall sharpen our swords."16

All of the four religiously oriented political parties were closed, three of them by the Constitutional Court and one in the aftermath of the 1980 military intervention. In the late 1990s the Turkish Hezbollah, a small Islamic movement community, aimed at creating a pristine Islamic state, if necessary by killing the "unbelievers." The movement was neutralized in 2000.

In the wake of the November 2002 and July 2007 national elections, the "religiously oriented" JDP garnered adequate seats in Parliament and formed majority governments. Furthermore, following the 2007 national elections, the JDP has elected in Parliament one of its members as the president of the republic. These two developments together constituted the last straw: the secularists became alarmed. Despite the JDP leaders' insistence that, although devout persons, they preferred secular politics (and acted accordingly), the secularists expected the worse. The latter, in particular, thought that the JDP was going to allow covered women to attend colleges and work in the public bureaucracy. They were also of the opinion that the government may enforce Islamic dress codes for secularist women and that, even if that were not the case, the mere increase in the numbers of covered women would create enough pressure on secularist women that they would feel obliged to sport the turban. ${ }^{17}$ 
The interviews with Mardin were conducted two months before the 2007 national elections. During the almost five years that followed the 2002 elections, the secularists had already become very much concerned about the future of the secular republic. Mardin's remarks plus the 2007 elections, at which the JDP increased its vote percentage from 34.2 to 46.6, added fuel to the fire. The election of a JDP member to the presidency of the republic was another reason for the secularists' alarm, because the presidency in the Turkish political system, along with the Constitutional Court, has some significant powers over Parliament. ${ }^{18}$ The previous president of the republic who had sympathies with the secularists, did use some of those powers for preventing the JDP government from "setting up a state based on Islam."

\section{Does Secularism Face a Serious Threat in Turkey?}

Is the flourishing of a communally based Islamic fundamentalism a likely prospect in Turkey, as Mardin suggested in 2007 as a possibility and as Toprak and others have found some examples of? More specifically, are people in Turkey inclined to exert pressure on others to practice or not practice their religion and/or lead or not lead certain lifestyles? On the strength of a number of reliable nationwide surveys, including one by Toprak and another by prominent Turkish scientist Ali Çarkoğlu, I argue that that the answers to both questions should be in the negative.

Most people in Turkey are sympathetic toward both the secular republic and Islam. A 2006 nationwide survey found that 85.9 percent of respondents think that, in leading a modern lifestyle, the president of the republic should be a role model for the people, and 75.2 percent were of the opinion that the president should act as the guardian of secularism. However, 74.3 percent of the same set of respondents also indicated that the president of the republic should be a practicing Muslim. ${ }^{19}$ The same survey found that when people vote, they act in a similar manner: 84.2 percent have pointed out that they vote for political parties that, they think, have internalized secular republican values, and 78.2 percent wish to see that the same political parties respect their Islamic values and sentiments and pursue policies along those lines. ${ }^{20}$

That people think that Turkey should be a secular republic and at the same time wish that political parties would act responsively to their religious preferences and sentiments should not be seen as a paradox. The great majority of people in Turkey are practicing Muslims. Islam for them is on the one hand a system of belief and on the other a source of ethics, values, and attitudes. Religion (Islam) has continued to shape the cultural makeup of an overwhelming majority of Turks. This is because the Turks have not 
had either a hegemonic aristocracy or a bourgeoisie, and therefore have not emulated those values and attitudes. Kemalism, in the final analysis, was a cognitive revolution; it was not and could not be a cultural revolution. A great majority of the Turks learned to use their reasoning faculties. In the process, the leaders of the JDP turned out to be devout persons (not only in practicing their religion but also in deriving certain values from their religion), but they preferred running state affairs essentially in a secular manner. ${ }^{21}$

In later decades, while a majority of people practiced their religion, on the whole they did not vote for a political party only because it was religiously oriented. In the 1973 and 1977 national elections in Turkey, only one religiously oriented political party competed - the National Salvation Party (NSP). Like the decades that succeeded it, the 1970s were considered a period when Islam was on the rise both in Turkey and around the world. Yet while in the 1973 national elections the NSP garnered 11.8 percent of the vote, its vote percentage dropped to 8.6 in the 1977 elections. In the 1990s, the only religiously oriented party was the Welfare Party (WP). It obtained 16.8 percent of the votes in the 1991 national elections. In the 1994 local elections, the WP captured the metropolitan mayoralties in several urban centers, including some major ones. The mayors of the WP performed well, one being Recep Tayyip Erdoğan of the Istanbul metropolitan municipality. It was for this reason in particular that in the 1995 national elections, the WP's vote percentage increased from 16.8 to 21.4 (a plurality of votes). The party became the senior member of the coalition government that it managed to form with a secularly oriented party (the True Path Party), and whose leader, Erbakan, became prime minister. In 2002 and 2007 two religiously oriented political parties participated in the national elections-the Felicity Party (FP) and the JDP. The FP presented itself as basically religiously oriented party and its program did not hide this fact. In contrast, the JDP pronounced itself a "conservative-democratic" party, and while in government from 2002 to the present it essentially acted as such. In the 2002 and 2007 national elections, the FP obtained only 2.49 percent and 2.33 percent of the votes, respectively, whereas the JDP in those elections received 34.43 percent and 46.66 percent of the vote, respectively.

Hard-core Kemalists fearful of "fundamentalist Islam" are not tolerant toward those they consider adherents of this form of Islam. However, most Turks as Muslims display loyalty to the secular republic; they are inclined not to mix religion and politics, and they are tolerant toward other people on religious matters. These particular traits on the part of most Turks result from a number of factors. As compared to other Muslim states, the Ottoman state was the least theocratic; from the fifteenth century onward, 
laws based solely on sultan's decree took their places alongside the sharia. The Ottoman society itself was a mosaic of peoples who lived side by side and, consequently, experienced a certain degree of mutual acculturation. Having learned to live together in relative harmony, they developed tolerance as acceptance. In Ottoman times, this particular attitude in matters of religion was often expressed as, "Your religion to you, my religion to me."22

This particular Ottoman heritage of the modern-day Turks is reflected in their tendency to regard those who are different as odd and thus as the "other." Nationwide surveys conducted in 1999 and 2006 found that a person who believes in Allah (the Muslims' God) and his Prophet Muhammad is considered Muslim by 84.8 percent and 79.9 percent of the respondents, respectively, even if that person does not do his or her prayers. ${ }^{23}$ The same survey found that 75.2 percent of respondents did not object to having neighbors who had a different sectarian preference. ${ }^{24}$ The findings of a 2006 nationwide survey summed up the tolerant attitude of the Turks as Muslims toward other Muslims in an unequivocal manner: only 8.2 percent of the respondents opposed the view that people have the right to practice their religion in a manner they see fit. ${ }^{25}$

What are the attitudes of people in Turkey toward the question of tesettür (women covering themselves)? Before I take up this issue, an indication of the types of covering in Turkey, of those that are matters of contention and those that are not, and why, is in order. In Turkey, the scarves that women use to cover their head are the çarşaf, headscarf, turban, and yeldirme. The çarşaf, similar to the chador in Iran, is a cloak made up of black light cloth that completely, but loosely, covers the whole body, including the hair and neck but excluding feet, hands, and face (and in Turkey in rare cases only eyes). The secularists view the çarşaf as an Islamic outfit and not a modern one, and consequently they are dead set against it. However, since women wearing the çarşaf often stay out of the neighborhoods where most of the secularists reside, work, and otherwise are present this outfit is less controversial than the turban. The headscarf (başörtüsüleşarp/yemeni) covers part of the hair and sometimes also part of the shoulders, is tied loosely underneath the chin, is usually of pale color, and is worn by older women. Young secularists stay away from it; however, it is not made a matter of contention by the secularists in general. The turban covers all hair, the neck, and sometimes the shoulders, too. The secularists take this type of cover as a symbol of political Islam and are opposed to turbaned women (as well as those wearing the çarşaf) entering the "public sphere"; the debate in Turkey among the secularists and their detractors on the question of what constitutes the public sphere is ongoing. This version of the turban is distinguished from the essarp in Turkish, a type of turban often of a bright color that is tied at the 
back of the neck and does not cover the shoulders, the neck, and all of the hair. This version of turban is worn by some secularist women. The yemeni, a kind of light cloak often sported by women in small towns and villages, is hardly mentioned in the debates on the covering of women.

It should be underlined here that, in contrast to both the secularists and their detractors, ordinary people in Turkey do not perceive the question of the headscarf/turban as an important problem. In a nationwide survey carried out in 2006, less than one percent of respondents considered "religion or religious practices" a problem for the country. ${ }^{26}$ Similarly, in another nationwide survey conducted that same year, only 3.7 percent of respondents perceived the headscarf/turban issue as problematic. ${ }^{27}$

That most Turks do not consider the turban problematic must be a consequence of their tendency to stay away from political Islam. This issue was investigated in the 1986, 1995, 1996, 1998, 1999, 2002, and 2006 nationwide surveys, whose findings are given in table 4.1.

From the surveys' results, one might ask how a claim that the Turks stay away from political Islam can be made when respondents, ranging from oneforth in 1996 to one-fifth in 1995, 1998, and 1999 and close to one-fifth in 2002, came up with affirmative answers when asked whether or not

Table 4.1 Do people in Turkey long for a state based on Islam?

\begin{tabular}{lc}
\hline Years & Affirmative Responses (\%) \\
\hline $1986^{*}$ & 0.7 \\
$1995^{* *}$ & 19.9 \\
$1996^{* *}$ & 26.7 \\
$1998^{* *}$ & 19.8 \\
$1999^{* * *}$ & 21.0 \\
$2002^{* * * *}$ & 16.4 \\
$2006^{* * *}$ & 8.9 \\
\hline
\end{tabular}

Sources:

${ }^{*}$ Nokta, October 19, 1986, cited in İlter Turan, "Religion and Political Culture in Turkey," in Islam in Modern Turkey: Religion, Politics and Literature in a Secular State, ed. Richard Tapper (London: I. B. Tauris, 1991), 55, footnote 42 .

**Türkiye Sosyal, Ekonomik ve Siyasal Araştırmalar Vakfi (Social, Economic, and Political Studies Foundation of Turkey), Türkiye'de siyasi partilerin seçmenleri ve sosyal demokrasinin toplumsal tabanı (The Electorate of Political Parties and Social Base of Social Democracy in Turkey) (Ankara, 1996).

***Ali Çarkoğlu and Binnaz Toprak, Değişen Türkiye'de din, toplum ve siyaset (Religion, Society, and Politics in Changing Turkey) (Istanbul: TESEV, 1999).

**** Çarkoğlu and Kalaycıŏlu, Turkish Democracy Today. 
they long for a state based on Islam. One may arrive at the conclusion that the Turks stay away from political Islam for a number of reasons. First, as already noted, for people in Turkey, religion and religious issues in general and the headscarf/turban issue in particular are not significant concerns. If this is indeed the case, then why would one-fourth to one-fifth of people toy with the idea of a quantum jump from a secular system of government to an Islamic one? Second, when respondents were asked whether they long for a state based on religion, that is, on the sharia, their answers implied that on the whole they do not have a clear idea of what sharia rule would be like. Turkey's prominent social scientists Çarkoğlu, Ersin Kalaycıoğlu, and Toprak have also arrived at this conclusion. According to Çarkoğlu and Kalaycioğlu, "Such findings suggest that approval of Şeriat [sharia] rule may simply be a proxy for reactions reflective of economic and political unease in the country rather than being a radical turn toward religion based on legal and political order in the country." 28 Toprak is also of the opinion that the affirmative responses to the question of whether people long for a sharia state would not by themselves indicate that the respondents have in mind what a sharia state would entail. ${ }^{29}$

As table 4.1. illustrates, in the 1999 survey carried out by Çarkoğlu and Toprak, 21 percent of the respondents answered in the affirmative when asked whether they preferred a state based on Islam to the one based on secularism. Taking this finding at face value could create shock waves in a country that underwent quite a successful cognitive revolution. However, responses to some other related questions in the same survey make it clear that to the participants the term "sharia state" indeed connotes a meaning different from what sharia rule really implies. Among other things, the sharia allows men to marry up to four wives and stipulates the stoning to death of women who commit adultery. When the respondents were asked whether men should be allowed to marry up to four wives, the affirmative response rate dropped from 21 percent to 7 percent, and when they were asked whether women who commit adultery should be stoned to death, the affirmative response rate plummeted to less than 2 percent.

It seems that approximately one-fifth of the people in Turkey long for a better life than the one they have; by their admission, such a life may be possible under a state different from the present one; and they refer to that different state as a sharia state. Since 2002 Turkey has been ruled by a conservative-democratic government. In the 2006 survey, those who long for a sharia state dropped from 21 percent to 9 percent. Could there be a relationship between the two phenomena? To judge the validity of such a hypothesis additional empirical data would be needed.

As noted above, particularly from 2002 to the present (the years the JDP has been in government), the covering issue has become a matter of bitter 
confrontation between the JDP and the secularists. The secularists took the turban in particular as a symbol of a movement against the secular premises of the republic. Also, they opposed the çarşaf even more fervently; however, since the women wearing the çarşaf are less in the public eye, the conflict has revolved primarily around the turban. In a related manner, the secularists have also concluded that the number of women wearing turbans is increasing by the day and this could soon place moral pressure on uncovered women to cover themselves.

How widespread is covering among women in Turkey? What are the coverings most used in that country? Do more people cover as time goes by? The 1999 and 2006 surveys have investigated these questions (see table 4.2). As the findings show, in 1999, 19.1 percent of women respondents wore the turban or çarşaf. In 2006 the number dropped to 12.5 percent.

An even more important question here is why women in Turkey cover themselves. Do they do so for the reasons that alarm the secularists in that country or for other reasons? The results of the 2006 Çarkoğlu-Toprak survey are presented in table 4.3. As the findings show, religious belief is the major reason women cover themselves. There is no reason, however, to jump to the conclusion that those women who cover themselves because of their religious belief would also champion religious fundamentalism at the level(s) of the community and/or political Islam. If that were the case, in the 2002 and 2007 national elections, the FP, openly religiously oriented party, would have received more votes and the JDP, a conservative-democratic party, would have garnered fewer. More significant, as is well known, religion may play a role at the individual, community, and/or state level. At the individual level, it is a source for ethics and morality. At the community level, it may be a road map for the individual in his or her interactions with other community members. At the level of state, religion turns into a political religion. If it plays a role at the individual level, it does not necessarily play a role at the community level and/or state level, as the secularists in Turkey tend to think.

Table 4.2 Women wearing the çarşaf, headscarf, and turban (\%)

\begin{tabular}{lcc}
\hline & 1999 & 2006 \\
\hline No cover & 27.3 & 36.5 \\
Headscarf & 58.4 & 48.8 \\
Turban & 15.7 & 11.4 \\
Çarşaf & 3.4 & 1.1 \\
\hline
\end{tabular}

Note: The yeldirme was not taken up in these surveys.

Source: Çarkoğlu and Toprak, Değişen Türkiye'de din, toplum ve siyaset, 1999, 2006. 
Table 4.3 Why women in Turkey cover themselves (2006)

\begin{tabular}{lc}
\hline & Reasons $\%$ \\
\hline Religious belief & 71.6 \\
Because others too cover themselves & 7.6 \\
Expression of identity & 3.9 \\
Getting around in society more easily & 1.2 \\
Wish of one's husband/fiancee & 0.9 \\
Being part of a political movement & 0.4 \\
Wish of one's father, mother, and/or & 0.2 \\
brother & \\
Other & 1.1 \\
No response & 8.2 \\
\hline
\end{tabular}

Source: Çarkoğlu and Toprak, Değģsen Türkiye'de Din, Toplum ve Siyaset, 1999.

Furthermore, in 2006, those women who indicated that they cover because they consider themselves part of a political movement was only 0.4 percent of the total population surveyed. It is difficult to determine what respondents mean when they say that they consider Islam as their identity. Nevertheless, when they are grouped with those who regard themselves as part of a political movement (i.e., political Islam), the percentage of the two categories together, among all the women interviewed, still remains low, at 4.9 percent.

One should also keep in mind that the population of the 2006 survey comprised women who covered themselves not only with the turban but also with other headgear. This means that turbaned women who use it as a symbol of Islamic fundamentalism/political Islam constitute even smaller percentage than 0.4 percent or 4.9 percent, as the case may be, among all the women who covered themselves at the time the survey was conducted.

Another significant finding of the 2006 survey is that a great majority of the women in Turkey do not cover themselves because of pressure exerted on them by their close relatives or partners, another widespread assumption on the part of the secularists in Turkey. When women who covered were also asked what they would do if some covered women around them started uncovering, 100 percent of $c_{\text {arş }} a f$ wearers, 94.1 percent of those sporting turbans, and 87.7 percent donning other headgear indicated that they themselves would not uncover. As already noted, the secularists fear that an increase in the number of the covered women could constitute a moral pressure on uncovered women and that they, too, would feel obliged to cover. This fear seems unreasonable: if the covered women whom the secularists look down on can stand 
Table 4.4 Why women in Turkey sport turbans

\begin{tabular}{lc}
\hline & Reasons \% \\
\hline Conformity with Islam's tenets & 68.0 \\
Displaying one's political preference & 14.9 \\
Acting in harmony with others & 7.4 \\
Displaying one's identity & 4.6 \\
Expression of one's morality & 3.1 \\
A means of self-protection & 2.1 \\
\hline Source: Tarhan Erdem, "Gündelik Yaşamda Din, Laiklik ve \\
Türban" ("Religion, Secularism, and Turban in Everyday Life"), \\
Milliyet, December 3-4, 2007.
\end{tabular}

against the presumed moral pressure from others on this side, then why should the more "modern" and "rational" secularists could not manage to do the same if indeed they themselves faced such a pressure?

I turn back to the presumed turban-political Islam relationship in Turkey, on the basis of a 2007 nationwide survey that also investigated why women wear the turban and whose findings corroborate those of the 2006 survey on the same issue (see table 4.4). The 2007 survey results indicate that for women, sporting the turban serves specific functions such as displaying one's political preference, expressing one's morality, or being a means of genderrelated self-protection from strangers. However, none of these additional functions can be considered in relation to political Islam; both the 2006 and the 2007 surveys show that for those who wear the turban, it is first and foremost a symbol of belief in Islam, and for only a few turbaned women it is a symbol of political Islam.

Some relatively recent qualitative studies based on in-depth interviews also have arrived at the conclusion that there is no generalized relationship between turban/çarşaf, and political Islam. These studies show that in many instances veiling, in fact, enables women to take advantage of the spaces modernity provides and thus to participate in economic, social, and political life, which they otherwise could not be a part of. ${ }^{30}$

\section{Conclusion}

In his well-known Foreign Affairs article in 1993, Samuel P. Huntington foresaw a clash of civilizations among the constellations of countries divided from one another in terms of religion, history, language, and traditions. In this context, Huntington regarded Turkey as a "torn country," and categorized it as a member of a civilization rival to the Western one. ${ }^{31}$ 
In religious terms, Turkey is not a torn country. For a great majority of its population, Islam plays a role only at the individual level, not at the community and state levels. And the same majority of people support and value the secular republic. Turks as Muslims have a great deal of tolerance toward their co-citizens' ways of practicing or not practicing and living and not living according to their religion. The secularists should not be scared of becoming an increasingly smaller and weaker minority in an increasingly religious society, because those whom the secularists regard as Islamists, in fact, display a great deal of tolerance (with respect) toward those who are different from themselves and, they at the same time, show loyalty to the secularist republic.

Since Turkey has gone through a cognitive revolution, Islam for the bulk of the people is not a source of superstitions and dogmas. On the whole, political Islam has no appeal to Turks. They are also not receptive to a community-based political Islam.

If there have been deep divisions in Turkey, those rifts have been around some hard and soft ideologies and only among some members of the intelligentsia. In recent years, the secularists have been rather hostile toward those people and politicians whom they consider retrogressive and who, in their opinion, would take Turkey back to the Dark Ages. In the process, they have held "republican demonstrations" and denounced "the retrogressives." The latter, however, have not reciprocated.

With Turkey having had a democratic revolution, the secularists could not come to power via elections, because for years they have looked down on the majority of people and thus given short shrift to their preferences and demands. Yet, in November 2008, Deniz Baykal, the leader of the political party of the secularists (the Republican People's Party, or the RPP), admitted women with turbans and even çarşafs into his party, and the party was careful to publicize the event. ${ }^{32}$ On the face of this "turn of events," this chapter could have concluded as follows: if this sudden volte-face on the part of Baykal was not made only for the sake of the upcoming local elections (March 2009), Turkey may soon mend fences also with some members of its intelligentsia and politicians and thus begin to enjoy a more consensual politics. However, it would not be appropriate to arrive at such a conclusion. For only five days after admitting covered women into the RPP, the party's vice chairman, Onur Öymen, was asked how the party could admit to its ranks women wearing turbans and çarşafs given the party's strict secularist stance. Öymen countered with a telling question: "How could the chairman of the RPP turn its back to the women with turbans and çarşafs who had wished to join his party, indicating that they had become fed up with the Justice and Development Party, and begun to identify themselves with 
the principles the RPP advocates?" He added that, once those people had joined the RPP, the republican women in the RPP would instruct them on the modern worldview. ${ }^{33}$ True to the long-time approach of his party on this issue, secularist Öymen was not willing to meet with the "Islamists" at a consensual midpoint; instead, he was inclined to instruct them about the secularists' "truth".

\section{Notes}

1. Mardin used the phrase "mahalle baskisi" (the pressure of the neighbourhood). See Ruşen Çakır, comp., Mahalle Baskısı: Prof. Dr. Şerif Mardin'in tezlerinden hareketle Türkiye'de Islam, cumburiyet, laiklik ve demokrasi (The Pressure of the Neighborhood: Professor Şerif Mardin's Views on Islam, Republic, Secularism, and Democracy) (Istanbul: Doğan Kitap, 2008).

2. On the JDP and state-based Islam, see, e.g., Kudret Cengiz, Anti Kemalist devrim (Anti-Kemalist Revolution) (Istanbul: Pozitif Yayınları, 2008); Sabih Kanadoğlu, Alaturka demokrasi (Democracy Unique to Turkey) (Ankara: Arkadaş, 2004); Erol Manisalı, İslamcı siyaset ve cumburiyet (Islamic Politics and the Republic) (Istanbul: Derin, 2006); Vural Savaş, AKP Çoktan Kapatılmaliydı (The Justice and Development Party Should Have Been Closed Long Ago) (Ankara: Bilgi, 2008).

3. See, e.g., Metin Heper, "The Conservative-Democratic Government by Pious People: The Justice and Development Party in Turkey," in Blackwell Companion to Contemporary Islamic Thought, Ibrahim M. Abu-Rabi, ed. (Oxford and New York: Blackwell, 2006), 345-61; Berna Turam, Between Islam and State: The Politics of Engagement (Stanford, CA: Stanford University Press, 2007); Hakan Yavuz, ed., The Emergence of a New Turkey: Democracy and the AK Party (Salt Lake City: University of Utah Press, 2006).

4. The full texts of the two interviews with Mardin are in Çakır, Mahalle baskısı.

5. Ibid, pp. 23-24, 89.

6. Binnaz Toprak, Proje Sorumlusu (Director of the Project), "Türkiye'de farklı olmak: Din ve muhafazakarlık ekseninde ötekileştirenler" (Being Different in Turkey: Those Who Are 'Othered' on the Basis of Nationalism and Conservatism) (typescript, Istanbul, December, 2008).

7. In 1934, Mustafa Kemal was given the last name "Atatürk" (father of Turks) by the Turkish Grand National Assembly.

8. The Caliphate was an Ottoman religious institution and was headed by the caliph, the Islamic spiritual leader who could legislate in areas not covered by the Sharia. The fez was first begun to be worn by the members of the Ottoman court during the reign of Sultan Mahmud II (r. 1808-1939). At the time, it, too, was taken as a symbol of modernity.

9. On these reforms, see Metin Heper, "Islam, Polity and Society in Turkey: A Middle Eastern Perspective," Middle East Journal 35 (1981): 345-63. 
10. See Metin Heper, The State Tradition in Turkey (Beverley, North Humberside, U.K.: The Eothen Press, 1985), chap. 3.

11. Metin Heper, "Islam and Democracy in Turkey: Toward Reconciliation?" Middle East Journal 51 (1997): 34-35.

12. Ibid., p. 35.

13. Şerif Mardin, Din ve Ídeoloji (Religion and Ideology) (Ankara: Sevinç, 1969), 132.

14. Tarhan Erdem, "İşte KONDA'nın Kürt Raporu," (The Report on the Kurds by KONDA), Milliyet,16 August 1995.

15. In this article "secularists" refers to those people who tend to think that people who practice their religion and/or put on what they think is an Islamic outfit are not modern people; the latter would make rational decisions and have a Western style of life, including such dress codes. In the view of the secularists, the people whom they criticize in above terms long for a state based on Islam.

16. Gareth Jenkins, Political Islam in Turkey: Running West, Heading East? (Houndsmills, Basinstokes, U.K.: Palgrave Macmillan, 2008), 138.

17. In the process, members of the founding generation of the republic began to feel deep nostalgia for the "good old days." See, Esra Özyürek, Nostalgia for the Modern: State Secularism and Everyday Politics in Turkey (Durham and London: Duke University Press, 2006).

18. According to the Article 104 of the 1982 Turkish Constitution, the powers the president of the republic shall exercise include (1) promulgating laws, (2) returning laws to Parliament for reconsideration; (3) submitting to referendum; if he or she deems it necessary, legislation regarding the amendment of the constitution; (4) appealing to the Constitutional Court for the annulment in part or entirety of certain laws, decrees having the force of law, and the rules of procedure of the Parliament on the grounds that they are unconstitutional in form and content; and (5) calling for new elections. Constitution of Republic of Turkey, http//www.constitution.org/cons/turkey/turk_cons.htm.

19. Ali Çarkoğlu and Binnaz Toprak, Türkiye'de din, toplum ve siyaset (Religion, Society and Politics) (Istanbul: TESEV Publications, 2006), 92.

20. Ibid., p. 81.

21. I say "essentially," for these leaders respect the man on the street, emphasize helping the needy, and ask Muslim jurists at mosques to speak in their sermons to the male members of their congregants of acting affectionately, not resorting to violence toward their wives - all of which, of course, have religious colorings; yet, these same leaders are no different from secular leaders when it comes, for example, to addressing Turkey's foreign relations, economics, and the like

22. For a discussion of the Ottoman heritage of the present day Turks, see Metin Heper, The State and Kurds in Turkey: The Question of Assimilation (Houndsmills, Basingstokes, UK: Palgrave Macmillan, 2007), chap. 2.

23. Çarkoğlu-Toprak, Türkiye' de din, toplum ve siyaset, 71

24. Ibid., 47.

25. Ibid., 51 
26. Ali Çarkoğlu and Ersin Kalaycıŏlu, Turkish Democracy Today: Elections, Protest and Stability in an Islamic Society (London: I. B. Tauris, 2007), 152.

27. Çarkoğlu andToprak, Türkiye'de din, toplum ve siyaset, 23.

28. Çarkoğlu and Kalaycıoğlu, Turkish Democracy Today, 126.

29. According to one definition, which is adequate for the purpose of this article, the Sharia is a body of rules that regulates the conduct of the Muslim; it covers not only belief and ritual but also matters of custom and law. Niyazi Berkes, The Development of Secularism in Turkey (Montreal: McGill University, 1964), 9, cited in Çarkoğlu and Kalaycioğlu, Turkish Democracy Today, 124. This definition of the Sharia draws on Berkes's but is somewhat different from of Çarkoğlu and Kalaycioğlu's.

30. Yeşim Arat, Political Islam in Turkey and Women's Organizations (Istanbul: Friedrich Ebert Stiftung and the Economic and Social Studies Fouindation of Turkey, 1999), 61; Ali Bayramoğlu, Çă̆daşlık hurafe kaldırmaz: Demokratikleşme sürecinde dindar ve laikler (Modernity Does not Leave Space for Superstitions: Devout and Secular in the Democratization Process) (Istanbul: Türkiye Ekonomik, Sosyal ve Siyasal Araştırmalar Vakfi, 2006), 139; Alev Çınar, "Clothing The National Body: Islamic Veil and Secular Unveiling," in Modernity, Islam, and Secularism in Turkey: Bodies, Places, and Time (Minneapolis: University of Minnesota Press, 2005), chap. 2; Sema Genel and Kerem Karaosmanoğlu, "A New Islamic Individualism in Turkey: Headscarved Women in the City," Turkish Studies 7 (2006): 473-88; Nilüfer Göle, The Forbidden Modern: Civilization and Veiling (Ann Arbor: The University and Michigan Press, 2001), 137-40; and Elisabeth Özdalga, The Veiling Issue, Secularism and Popular Islam in Turkey (Surrey, U.K.: Curzon Press, 1998), 55-85.

31. Samuel P. Huntington, "The Clash of Civilizations?" Foreign Affairs 72 (1993): 42.

32. "CHP'den çarşaflı türbanlı Şov," (“The RPP Show with Turban and Chador”) Radikal, November 17, 2008.

33. "CHP'nin 'çarşaf' açıklamaları bitmiyor," (The RPP's Justifications for Chador Never Come to an End), Yeni Şafak, November 22, 2008. 